Wolff, J., 'Scanlon On Social and Material Inequality', Journal of Moral Philosophy (2013), 10:4, pp.406-425. 10.1163/174552412X628977

\title{
ARTICLE
}

\section{Scanlon On Social and Material Inequality}

Jonathan Wolff, Department of Philosophy, University College London, Gower Street, London, WC1E 6BT

\begin{abstract}
Tim Scanlon's famous and important paper 'The Diversity of Objections to Inequality' sets out five reasons why those sympathetic to equality may object to inequality. This paper shows the origin of this approach to inequality in Scanlon's earlier work, and its persistence in his later work. It also compares Scanlon's position to earlier egalitarian writers, such as R.H. Tawney, and antiegalitarians such as J.R. Lucas. It concludes by suggesting that there are interaction effects between the reasons for objecting to inequality and hence they are more powerful if taken together.
\end{abstract}

Key words: Scanlon, Tawney, social equality, material equality, social class, domination

\section{Background and influence}

There is no doubt that Tim Scanlon has been an extremely influential figure in the recent development of egalitarian theory. His work has been cited in many of the leading contributions, and it is also clear that he has had an influence through discussions and communication with many of the most influential egalitarian theorists. Yet I think it is fair to say that when surveying the current debate, Scanlon's position is not easy to identify. Whereas others have a view with a distinctive descriptive name Scanlon's contribution has not (yet) been of this type. This, I'm sure, reflects an admirable preference for truth over brand recognition, but it will be worthwhile to see what can be constructed from some of his writings.

\section{[Page $407 \rightarrow$ ]}

\section{Equality and 'Preference and Urgency'}

Scanlon's first major contribution to the debate was his 1975 paper 'Preference and Urgency', published in the Journal of Philosophy as a paper presented in an APA symposium on equality, 
with replies at the conference, but as far as I know unpublished, from Milton Fisk and Gerarld McCullum (Scanlon, 1975).

Scanlon's seminal contribution was to point out the distinction between subjective theories of wellbeing, such as hedonistic or preference satisfaction theories, that assess an individual's well-being from the point of view of the person under consideration, and objective theories which provide accounts of well-being that are independent (to some degree) of the person's tastes and preferences. Furthermore Scanlon suggests that in recognizing claims and making decisions about the use of social resources we tend to use objective accounts. The main argument for this is based on the famous example of a religious person who would prefer to build a monument to his god rather than eat. Scanlon plausibly claims that as a society we are much more likely to feel the weight of the urgent need for food, rather than for help with building a monument, whatever the religious person himself prefers. The notion of urgency, Scanlon supposes, is related to the idea of 'a range of variation of normal lives'.

The point that the idea of equality is not straightforward has been exceptionally influential, perhaps sparking much of the contemporary debate. It is notable that two agenda setting contributions Sen's ‘Equality of What?' (1980) and Dworkin's two papers 'What is Equality?' (1981a and 1981b) both make reference to Scanlon's discussion. Yet the general point that there is no privileged single idea of equality was not entirely new, even if its particular presentation was novel. The basic idea is clearly articulated by Marx, in the Critique of the Gotha Programme (1875). A different version of the critique of the idea of equality, or at least of the socialist programme, is presented by Anton Menger in The Right to the Whole Produce of Labour (1899). Menger suggested that two different ideas frame the socialist programme: 'the worker's right to the whole produce of labour', and 'each according to their need'. But, Menger points out, as soon as one person has needs but cannot work, there is a tension between the two ideas.

From the observation that satisfying one egalitarian aim will lead to compromising another Marx concluded that it was wrong to build a radical emancipatory political programme on a demand for equality. Menger drew the conclusion that the socialist programme - of which it seems he was no friend - was hopelessly confused and thus should be rejected. Contemporary [Page $408 \rightarrow$ ] theorists, including, at least implicitly, Scanlon in 'Preference and Urgency', have drawn a different conclusion: that it is necessary to be clear about the notion of equality one defends.

In passing we should note that Scanlon also makes reference, in 'Preference and Urgency', to the problem of expensive tastes as a difficultly for subjective egalitarianism, and also discusses whether the objection to subsidizing expensive tastes is limited only to those tastes that have been deliberately created. In doing this Scanlon set off a line of debate in the literature that has been 
central to the project of attempting to formulate an egalitarian position, and which, though possibly now dormant is certainly not extinct and erupts into life every few years.

Clearly in 'Preference and Urgency' Scanlon reveals himself to be much more sympathetic to objective than subjective notions of well-being, at least for policy purposes, and his discussion of expensive tastes and intense preferences makes clear his opposition to some formulations of a principle of equality. Yet despite the tantalizing running head of the paper - 'Equality' reflecting the name of the symposium, rather than 'Preference and Urgency' reflecting the name of the paper there is little more one can add about the shape of Scanlon's position on equality in this paper.

\section{Review of Nozick}

The following year Scanlon published 'Nozick on Rights, Liberty and Property' (1976), which was an extended review article of Anarchy, State, and Utopia. Forced to consider Nozick's Wilt Chamberlain argument that equality (or any other 'pattern') can only be maintained by coercion, Scanlon responds that 'There are many different concerns which lead people to call for greater equality, and not all of these involve a pattern in a fundamental way' (Scanlon 1976, p. 8).

The reasons cited by Scanlon for objecting to inequality include:

1) A concern about the absolute poverty of the worst off, which can be addressed by aiming for greater equality by redistributing from the rich.

2) Inequality can give the rich an unacceptable degree of control over the lives of the poor.

3) Inequalities are incompatible with healthy social relations and the development of genuine community.

4) Inequality requires special justification (which sometimes can be given) in a way in which equality does not.

\section{[Page $409 \rightarrow$ ]}

In the Nozick paper Scanlon does not explicitly endorse these reasons for opposing inequality, although the tone of the paper makes it clear that he is sympathetic.

\section{Diversity of Objections to Inequality}

Twenty years later, in his Lindley Lecture 'The Diversity of Objections to Inequality', Scanlon 
returns to the theme, noting that he worked out his own ideas on equality in reflecting upon Nozick, and citing his earlier review essay as providing a brief statement of some of the views now developed at greater length. In this paper he is finally prepared to claim the objections to inequality as his own, rather than those of one or more unspecified proponents of equality.

What were, in the Nozick paper, four objections became five. The first three appear to be the same as before (although numbers two and three have switched places in the list). The previous number 4 has disappeared, or perhaps replaced with two more substantive specifications of the previous broad objection. The idea, once more, is that there are several different reasons for objecting to inequality and favouring equality:

1) To relieve suffering or severe deprivation

2) To prevent stigmatizing differences in status

3) To avoid unacceptable forms of power or domination

4) To preserve the equality of starting places which is required by procedural fairness

5) Procedural fairness sometimes supports a case for equality of outcomes: notably if members of a group have equal claims then unless there are special reasons for inequality the benefits should be shared equally.

It is exceptionally useful and clarifying to have these grounds of equality set out and distinguished, in that the force of different points, and arguments against them, can be clearly assessed. It is also very helpful to see, as Scanlon points out, that the second and fifth objection appear to be the most clearly egalitarian of the five. However, it should also be noted that these are not precisely stated principles, but rather a classification of types of objection or principle. So, for example, both the difference principle and forms of luck egalitarianism can be placed under the fifth heading. Both presume that individuals have an equal claim, yet both, in their different ways, provide 'special reasons' for deviations from strictly equal shares: the [Page $\mathbf{4 1 0} \rightarrow$ ] difference principle if it makes the worst off better off; luck egalitarianism if it reflects choice of the relevant kind.

\section{Recent Writings}

In the last few years Scanlon has written a number of further papers relevant to the topic of equality. One, 'Justice Responsibility and the Demands of Equality' published in 2006, in a festschrift for Jerry Cohen, looks at the disagreement between Cohen and Rawls and makes little 
direct connection with our topic. Two other papers, both unpublished, have much greater relevance. One is 'Plural Equality' presented at a conference in honour of Michael Walzer, and the other is 'When Does Equality Matter?' first presented at a conference on equality at the Kennedy School, and presented variously since then.

The Walzer paper is in some ways sympathetic to Walzer's project in Spheres of Justice (Walzer, 1983) which is not surprising as Scanlon had earlier drawn on some of Walzer's ideas in Diversity. I will return to this below. Four of the five 'diversity' arguments appear in the Walzer paper (the missing argument is the 'humanitarian' one which is less relevant to the concerns of the paper). Thus there remains considerably continuity in Scanlon's ideas, and this impression is reinforced in 'When Does Equality Matter?' as the five arguments are laid out explicitly, and used in discussions of equality of opportunity and in discussion of whether there is a clash between liberty and equality.

The first four objections are presented in 'When Does Equality Matter?' in very similar terms to previous work, although it is clear that Scanlon is less happy with earlier formulations of the fifth objection, citing an insightful review by Paul Weithman (2004) but also making objections of his own that seem to be distinct from Weithman's concerns. The formulation offered in 'When Does Equality Matter?' is:

Equal Benefit: If each member of a group has the same claim that some individual or institutional agent, provide it with a certain benefit, and if that agent is obligated to respond to all of these claims, then that agent must, absent special justification, provide each member of the group with the same level of benefit. (p. 11)

The very fine details of objection 5 , however, need not concern us further here, however. The general shape of it remains broadly the same: notably it is, in a [Page $411 \rightarrow$ ] sense, doubly qualified. First, the principle is conditional: it is relevant only is there is a background equality of claim. Second, it permits deviations from outcome equality if special justifications apply.

\section{Scanlon's Equality}

Scanlon has presented a remarkably consistent view about the reasons for objecting to inequality, from his review of Nozick to his most recent, as yet unpublished, writings. Of course, the details have been subject to development, and the account has been applied in different contexts, but there is a surprising pair of (related) omissions in his account. One, most obviously, is the question of what society would have to be like if the objections to inequality would be overcome. In other words, can we discern a positive picture from the collection of negatives? Second, is it possible to 
overcome all the objections at once? This second omission is particularly striking given the important theme of 'Preference and Urgency' that perhaps has shaped the entire literature since: making people equal in preference satisfaction may not equally meet their urgent needs. Consequently, equality is not a simple notion and may have internal tensions. Furthermore, given that Scanlon's account emphasizes the importance of social equality (objection 2 ) and material equality (objection 5) one may wonder whether he is vulnerable to a recent line of discussion that claims to detect conflicts between the two goals (Wolff 1998, Anderson 1999, Scheffler 2003).

I will not explore this second question, of potential internal conlict, in detail here, as it is likely that any apparent tension between material and social equality will depend on how those goals are formulated in detail and implemented in practice, and there is little to be gained for present purposes by attributing particular interpretations of the ideals to Scanlon when he does not do so himself. However, I want to see whether a more positive picture of equality can be derived, and it will prove helpful to pursue this by considering what Scanlon says, comparatively, about objections 2 and 5 , or, as it will be more convenient to describe them, the concern for social equality and the concern for material equality. There are two passages of particular interest.

The first comparative passage is this:

Reasons of type 5 are at least as powerful as those to which 2 appeals but these reasons come in a variety of forms, which vary in strength. (207)

\section{[Page $412 \rightarrow$ ]}

Now, possibly there are various ways in which this passage could be read, but it is not to the present point to try to come to a definitive interpretation. Rather the passage prompts two questions. First, how can one tell which is the stronger of the reasons? Second, why does it matter? On the first issue, as far as I can tell Scanlon does not elaborate on, or give an argument for, the claim, and it is hard to know how that would be possible, beyond an appeal to intuition. But why would one make such a claim? Of course there may be a purely theoretical interest in determining the strength of a claim, but more generally there is a need to determine the relative strength of reasons when they come into conflict. However, as noted, Scanlon does not explicitly raise the question of possible conflict himself and as I have said, I do not intend to pursue this issue in more detail here.

The second passage is this:

This aim - the ideal of a society in which people all regard one another as equals - has played an important role in radical egalitarian thinking - a more important role than the idea of distributive justice which dominates much discussion of equality in our own time. (204-5) 
It will be illuminating, in fact, to consider the question of whether Scanlon is right about the comparative importance of conceptions of social and material in the history of egalitarian thought. Scanlon has confirmed in responding to a version of this paper that he has, in part, taken Rousseau and writers such as R.H. Tawney as representatives of the main current of earlier radical egalitarian writers. Indeed, the influence of Rousseau is apparent in a number of Scanlon's writings, including 'When Does Equality Matter?' (p. 19).

Rousseau, clearly, was more interested in other forms of equality than material equality, although he does make the famous remark that in the model of society he favours no one should be rich enough to purchase another or poor enough to need to sell themselves, although how this observation should be interpreted has been a matter of debate. Yet Rousseau's concern with division in society, and the importance of overcoming it, is as much, perhaps more, about domination (Scanlon's reason 3) as avoidance of stigma (reason 2). Indeed, Rousseau's concern is both individual and group based, in that he seems concerned not just about one individual being dominated by another, but by one group, or social class, being dominated by another group or class. Tawney too, as we will see in more detail shortly, was perhaps even more concerned by class domination than by the inequities of individual fortune. Consequently it appears that for Tawney, Scanlon's reasons 2 and 3 come together in an opposition to class-based [Page $413 \rightarrow$ ] stratification of society. It is interesting to note that discussion of social class has largely fallen out of philosophical accounts of equality and inequality at least since Rawls. For this reason much contemporary writing on equality seems sociologically rather anemic, at least when compared with earlier writing (and by earlier writing I would include Bernard Williams essay 'The Idea of Equality', first published in 1962). Of course the writings of Brian Barry (2005), Michael Walzer (1983) and those influenced by them are exceptions to this claim, as are the writings of those in a more explicitly radical or feminist vein, such as Nancy Fraser (Fraser and Honneth 1998), or Iris Marion Young (1990).

The route from Rousseau to Tawney appears to pass through the Victorian poet Matthew Arnold (author of Dover Beach). Arnold's essay ‘Equality' (1879) introduced the phrase 'The Religion of Inequality' which is the title of Chapter II of Tawney's Equality. Tawney, in his opposition to hierarchy, snobbery and servility acknowledges Arnold's influence on his thought, and so before looking in more detail at Tawney, it is worth taking a brief glance at Arnold's essay.

To set the context for his discussion, Arnold remarks:

When we talk of equality we talk of social equality; and for equality in this Frenchified sense of the term almost everyone in England has a hard word. (p. 49-50) 
The lamentable state of affairs in Victorian England, compared to then contemporary France, a hundred years after the revolution, is described by Arnold thus:

But you know how often it happens in England that a cultivated person ... talking to one of the lower class, or even of the middle class, feels, and cannot but feel, that there is somehow a wall of partition between himself and the other, that they seem to belong to two different worlds. Thoughts, feelings, perceptions, susceptibilities, language, manners, everything is different. Whereas, with a French peasant, the most cultivated man may find himself in sympathy, may feel that he is talking to an equal. ... And it may be carried beyond the range of mere conversation, it may be extended to things like pleasures, recreations, eating and drinking, and so on. In general the pleasures, recreations eating and drinking of English people, when once you get below that class which [has been called] the class of gentlemen, are to one of that class unpalatable and impossible. In France there is not this incompatibility. Whether he mix with high or low, the gentleman feels himself in a world not alien or repulsive, but a world where people make the same sort of demands upon life, in things of this sort, which he himself does. (71-2)

\section{[Page $414 \rightarrow$ ]}

Consequently, Arnold suggests:

The religion of inequality ... has the natural and necessary effect of materializing our upper class, vulgarizing our middle class, and brutalizing our lower class. (87)

According to Tawney and Arnold the 'religion of inequality' is characterized by a widespread belief, throughout society, in a natural social and economic hierarchy of society into social classes, based on inherited characteristics acquired largely through birth. It is clear that concerns about stigmatizing differences of class membership and social role are of great concern to Tawney, and, at least in some cases, seem more important than material concerns:

What the working class movement stands for, what makes it of permanent significance, and not merely the clamour of a mob for comfort and amusements, is obviously the idea of social solidarity, as a corrective to the exaggerated emphasis on individual advancement through the acquisition of wealth. It is a faith in the possibility of a society in which a higher value will be set on human beings, and a lower value on money and economic power, when money and power do not serve human ends. (36)

Tawney makes explicit the idea that social equality is more important than material equality: 
What is repulsive is not that one man should earn more than others, for where community of environment, and a common education and habit of life, have bred a common tradition of respect and consideration, these details of the counting-house are forgotten or ignored. It is that some classes should be excluded from the heritage of civilization which others enjoy, and that the fact of human fellowship, which is ultimate and profound, should be obscured by economic contrasts, which are trivial and superficial. (154-5)

Yet it is certainly not the case that the avoidance of stigma and humiliation is Tawney's only concern, and not clear that he regards it as the most important. Indeed, reading Tawney through Scanlon is exceptionally illuminating, as all of Scanlon's objections to inequality can be found, though less systematically presented, in Tawney's writing.

Let us take Scanlon's objections in turn. The first, a humanitarian concern with the plight of the least advantaged is apparent through at least part of Tawney's discussion. He clearly applauds the fledgling welfare state of the early part of the $20^{\text {th }}$ century, making very favourable comparisons with the plight of the poor of Victorian England, just as few decades earlier. Yet much remains to be done, he observes, noting that a million children in [Page $415 \rightarrow$ ] England and Wales still suffer from 'physical defects' at any one time (p. 160) and Equality is full of discussion of the relation between poverty and illness.

In this connection it is very interesting to note Tawney's discussion of health inequalities in the UK. He takes as his example inequalities in Glasgow, contrasting the crowded and poverty-striken Gorbals ward, with a death rate of 17.2 people per thousand, with the 'well-to-do' Cathcart ward, with a death rate of 8.7. Other health indicators listed show similarly striking disparities (p. 193). Today, though, there is no longer such a marked difference between Gorbals and Cathcart: not because of social equality in health has been achieved but because the 'gentrification' of Gorbals and extensive housing development in Cathcart have changed the social demographics. The WHO Commission on the Social Determinants of Health, reporting in 2008, also chose Glasgow to illustrate health inequalities; this time Calton, in Glasgow, with a male life expectancy at birth of an astonishing 54, and Lenzie, a village six miles from Glasgow, with a male life expectancy at birth of 82 (p. 32). As Scanlon himself notes, although presented as an inequality, what is so disturbing need not be the fact of the difference in itself. Rather the fact that some people do so much better seems to suggest that the poor health of those at the bottom is avoidable, and could, at least to a high degree, be remedied by appropriate action, and hence is essentially a humanitarian concern. However, as Scanlon also suggests, considerations of equality could be engaged when differences 
in health are the result of the maldistribution of resources over which all concerned may have an equal claim. This, would, therefore, trigger objection 5 as well as objection 1.

We see, therefore, Tawney appealing to Scanlon's first objection to inequality: that it sometimes involves poverty or suffering at a level that engages humanitarian concern. The second objection was that of stigmatizing differences, and this has already been shown to be an important concern for Tawney. Yet much of Tawney's discussion concerns objection 3, regarding power and domination. Just to take one example, Tawney notes that, at the time he was writing, most of the leading figures in the civil service and law were drawn from relatively small group of upper and professional classes and educated at small number of elite schools. He acutely observes that a particularly unfortunate effect of such social stratification is that many of those in high authority will never have mixed - even as children - with those over whom they hold power (p. 92) something that perhaps has still not changed very much today in many countries.

\section{[Page $416 \rightarrow$ ]}

But inequality of power, in itself, is of central concern for him:

There is inequality of power, in virtue of which certain economic groups exercise authority over others. ... [This] is specially characteristic of the relations between the different classes engaged in production, and finds its most conspicuous expression in the authority wielded by those who direct industry, control economic enterprise, and administer the resources of land, capital or credit, on which the welfare of their fellows depends. (152-3)

It is clear that Tawney believes that domination of this sort, based on arbitrary privilege, and reproduced over the generations, is bad both in itself and in its effects on equality of opportunity, a topic to which he devotes substantial attention, and Scanlon's fourth ground for objecting to inequality, to which we turn next.

Tawney, like many modern writers, is especially critical of the notion of careers open to talents, against a background of great, class-based, inequality in educational opportunity. Yet as Tawney further argues, a society that formally opens up opportunity to all, while allowing only the very exceptional from lower classes to join the highest ranks, is barely an improvement. Tawney is often quoted for his image of 'tadpole society': a society in which while many tadpoles are born, and in principle any of them could become frogs, in practice only a very few do. There seem to be two quite distinct social criticisms combined in this image, one explicit and one a background assumption. The explicit point is that prized social position will be very scarce for those in the competition. The background assumption is that prized positions will often be available to 
members of the elite without the struggle. Equality clearly opposes this latter state of affairs. What it should say about the former is more difficult, and I will return to it.

The fifth objection to inequality I have described as a concern for material equality, in that it is concerned with procedures for the distribution of benefits. As we noted, Scanlon's own statement of this objection is subtle and nuanced, and has undergone development. The version of it used above was as follows: "if a group have equal claims then unless there are special reasons for inequality the benefits should be shared equally."

Interestingly, Tawney, in effect, ironically suggests that the industrial capitalism of his day would be able to defend itself as being largely in accordance with Scanlon's principle:

The inequalities of the old regime had been intolerable because they had been arbitrary ...The inequalities of industrial society were to be esteemed, for they were the expression of individual achievement or failure to achieve. They were twice blessed. They deserved moral approval, for they corresponded to merit. [Page $417 \rightarrow$ ] They were economically beneficial, for they offered a system of prizes and penalties. (136)

In other words, the inequalities of capitalism could be defended both on grounds of desert and efficiency. Tawney, no doubt, thinks that both defences are fanciful, but it is interesting to see his writing intersect with Scanlon's in this way.

Tawney does, though, have a concern for material equality. He argues:

A common culture cannot be created by merely desiring it. It rests upon economic foundations. It is incompatible with the existence of too violent a contrast between the economic standard and educational opportunities of different classes, for such a contrast has, as its result, not a common culture, but servility or resentment on one hand, and patronage, or arrogance, on the other. It involves, in short, a large measure of economic inequality - not necessarily, indeed, in respect of the pecuniary incomes of individuals, but of environment, of habits of life of access to education and the means of civilization, of security and independence, and of the social consideration which equality in these matters usually carries with it. (41)

It seems, therefore, that for Tawney, material equality is not to be identified with equality of income or financial wealth. Indeed, he goes to great lengths to argue that equality is to be realized not by equalizing incomes but by means of common provision of goods such as education, health and basic housing where necessary, funded by progressive income tax. Furthermore, the value of 
material equality - once humanitarian concerns are met - is in large part derivative: material equality is needed as a means to social equality, which in turn is needed to overcome a range of undesirable social features.

Tawney does provide us with an alternative model of a good society

It is possible to conceive a community in which the necessary diversity of economic functions existed side by side with a large measure of economic and social equality, and in which, therefore, while the occupations and incomes of individual varied, they lived, nevertheless, in much the same environment, enjoyed similar levels of health and education, found different positions, according to their varying abilities, equally accessible to them, intermarried freely with each other, were equally immune from the more degrading forms of poverty, and equally secure against economic oppression. (87)

Now while this may be taken as a model of social equality, we can see that it describes an attempt to combine avoidance of stigma with a number of other valuable features. My own impression is that Tawney's abiding concern is the avoidance of arbitrary privilege, and its reproduction over the genertions, and this straddles a concern for the avoidance of stigmatizing difference, opposition to economic and social control and [Page $418 \rightarrow$ ] domination, opposition to social partition, and promotion of equality of opportunity. Each of Scanlon's objections 2, 3 and 4 are all prominent, and it is hard to say which is most important. We also saw that a version of objection 5 is present in somewhat muted form, as well as objection 1, especially when Tawney discusses the Victorian era (although he is also clear that the UK's problems are not yet a thing of the past).

But Tawney's was not the only voice in the debate. We noted above Anton Menger's criticism of the socialist tradition that it was fatally confused between two conflicting ideas: the right of the immediate producer to the whole worth of the product and each according to their need. Whether or not Menger is right about the depth of the conflict between these ideas, we can agree with him that they are both recognizable as important strands of socialist, and hence, egalitarian concern. And note that neither of ideal mentions social equality. Similarly, writing ten years later than Tawney, the economist Arthur Lewis, writing as a commentator rather than an advocate, suggests:

What socialists have wanted is to establish a society in which every child shall grow up in pleasant homes and attractive surroundings and with good educational opportunities; in which every adult shall be provided for in sickness and adversity; and in which the pensioner can take untroubled ease (Lewis 1949, 32-3). 
Note that this is purely material account of equality; it says nothing of the quality of social relations or of the distribution of power. Hence one may say to Lewis that this is certainly not all that socialists have wanted. But in conclusion of this lengthy discussion, while it is true that the idea of social equality, in terms of the avoidance of stigma, has been an important part of the egalitarian tradition, it is hard to be sure that it is, as Scanlon suggests, more important than material equality as an argument within the egalitarian tradition. Furthermore, it seems most powerful when combined with two other arguments, concerning domination and opportunity, bundled together in opposition to the 'religion of inequality', or in other words, objecting to the establishment and reproduction of class-based privilege.

\section{Achieving Social Equality}

Tawney's image of a society of equals is no doubt very attractive to many. The question then confronts us of why it has not been achieved. What, exactly, is the obstacle? One possibility is that a privileged class, with economic and political domination, and control of the mass media, have both [Page $419 \rightarrow$ ] a perceived interest in perpetuating an unequal society and the power to do so. Another possibility is that the problem goes deeper; the difficulty is somehow inherent in human nature. This was, in fact, the view of Freud, expressed in Civilization and its Discontents, written the same year as Tawney's Equality. In commenting on the communists' programme of attempting to abolish human hostility and aggression to one another by abolishing private property, Freud suggested that the psychological premises of this argument were untenable. Power and influence, he believed, would simply take another form, and aggression and hostility would return (Freud, 1930, pp. 112-4).

Freud's remarks concern the attempt to establish social equality by means of first establishing material equality. His claim is that material equality is not sufficient to the task for mutual antagonism can never be overcome; it can only be managed and contained. Although his own position is less forthright that Freud's, Scanlon agrees that there are severe obstacles to achieving social equality. The challenge, as he sees it, is that even when arbitrary and unjust forms of discrimination are overcome, inevitably some will have talents and traits that are highly prized and the resulting 'meritocracy' may aggravate perceived differences in status (Scanlon, 1996).

Once more it is instructive to compare Scanlon's position with another writer on equality, this time not Matthew Arnold or R.H. Tawney, but the strident critic of equality J.R. Lucas. Like Scanlon, Lucas is keen to endorse a humanitarian argument for poverty reduction, and also to distinguish it from egalitarian arguments. In a paper entitled 'Against Equality' he writes:

Universal Humanity, will produce some of the conclusions the egalitarian looks for, but not 
the essentially egalitarian ones. Whenever inequality results in some people having too little, the humanitarian will protest as well as the egalitarian. Human life cannot be properly lived in very straitened circumstances, and we do not show respect for human beings as such if we do not try to alleviate those conditions. Moreover, wealth and poverty are, in part, relative terms: it is not just that there is a certain minimum requirement of food and fuel - true though this is: there is also a varying, and in our age rising, level of normality in each particular community, and to be too far below this will preclude a man from participation in the normal life of that community. The pre-war poor scholars in Oxford did not usually suffer from undernourishment: but their poverty did prevent them living the normal life of an undergraduate, and could be objected to on those grounds alone. Not only bread, but Nescafe and books are necessaries of university life - of social existence rather than bare physical subsistence.

This argument, the argument of the rising minimum as I shall call it, is by far the most pervasive argument in political thought today. It is a telling argument, but it is open to abuse. It may be a good thing that nobody should be without [Page $420 \rightarrow$ ] a television set: but it is only one desideratum among many; it does not have, though sometimes pretends to have, the compelling force of the claim that nobody should be without food. (302)

Commenting on what are for Scanlon objections 2 and 3, Lucas continues:

Power cannot be equally divided and distributed over the whole population. It is necessarily concentrated in few hands. Egalitarians may take steps to make the possession of power in some sense more equal, but even in so doing they admit its natural inequality. ...

Besides an inequality of power, there is an inequality of prestige, which will arise in any society which is in Durkheim's phrase 'a moral community '- whose members, that is, share values and have some ideals in common. It will stem from men's natural inequality of ability resulting in their being able, some to a greater, others to a lesser, extent to be successful in achieving their ideals. There will thus be an inequality of success, and therefore also of prestige, which has nothing to do with power or sanctions. (304)

And so Lucas concludes, in a vein not unsimilar to Freud,

We can secure Equality in certain respects between members of certain classes for certain purposes and under certain conditions; but never, and necessarily never, equality in all respects between all men for all purposes and under all conditions. The egalitarian is doomed to a life not only of grumbling and everlasting envy, but of endless and inevitable 
disappointment. (306)

Returning to the theme ten years later, in a paper entitled 'Against Equality Again' Lucas presses the argument further, suggesting that the demand for social equality is mistaken. Essentially, Lucas suggests, the value that leads theorists to advocate social equality - a secure sense of each person's own worth - is much better supported in some forms of unequal society. He writes:

It is essential to society, and, ... essential to each man's emotional fulfilment that there should be some differentiation in the structure of our society and in our social relations one with another. The full-blooded argument from fraternity to equality fails because it is founded on a premiss which is false in fact. We are not all brothers. (266)

Notoriously, Lucas expands:

It is better to be a bathroom attendant in an Oxford college than to be a prosperous proletarian in an amorphous plebs, because the bathroom attendant, although he occupies a relatively lowly place in the college hierarchy, nevertheless is enabled to feel that he is a valued member of that society, making a real and definite contribution to its well-being. In comparison, a modern egalitarian society can be very heartless, showing no concern for any individual as such. Although the prosperous proletarian has more money than [Page 421 $\rightarrow$ ] the college servant, and although he is not obliged to regard anyone as his superior, he does not feel that he is valued for himself alone, or that society cares for anything but his cash. A society which accords respect to each man in his place is appreciated because it seems to individuate individuals in a way in which societies committed to the egalitarian ethos are unable to do. If the only social relations are transitive symmetric relations, then I necessarily stand in exactly the same relationship to society as anybody else, and therefore I can have no social position which is peculiarly my own. Since my relationship to the rest of society is the same as yours, it would not make any difference if I were replaced by you; and from this it follows that I in myself am replaceable, and therefore dispensable. In a totally egalitarian society I am always potentially redundant. I am merely a unit, not a unique individual. If I see myself as a man, with a real personality and a real contribution all of my own to make to my fellow men, then I shall reject the ethos of egalitarianism and see positive merit in a social order which acknowledges the distinctiveness of the individual and therefore the differences between men. (266-7)

Whether or not Lucas's example is well-chosen, or well-supported by the evidence, we can, nevertheless, see his point. Freud argued that material equality is insufficient to achieve social equality. Lucas in his first paper made a different observation, also made by Scanlon, that it is highly likely that there will always be some emerging hierarchy which is an obstacle to social 
equality. In this second paper Lucas makes a somewhat different claim: that social equality is insufficient for providing each person with a secure sense of self-worth, and in fact an unequal society would do better.

What, then, can an egalitarian do to preserve social equality in the face of these difficulties? Scanlon considers two options The first is highly reminiscent of Tawney:

Even a highly differentiated meritocratic system of offices and rewards might not undermine the self-respect of those who are not successful in it if the attainments which it recognizes and rewards are regarded as less important indices of self-worth than good moral character, conscientiousness as a citizen, and devotion to the well-being of one's family and friends. (Scanlon 1996, 216)

The second possible strategy, and the one to which he devotes more attention, is what he calls diversification, which is to be found, in different ways, in Rawls and Walzer. Somewhat surprisingly, it is also to be found in Lucas:

Each man wants to be respected. The egalitarian seeks to satisfy this need by ensuring that no man is ever in an inferior position vis-a-vis anybody else, and so insists that all social relations shall be equivalence relations. That fails to meet the need, which is much better met by allowing relations which are asymmetric but securing for each man that there is some relation with respect to which he is superior to other people. No one should be always the underdog. [Page $422 \rightarrow$ ] We can object to strictly hierarchical societies on the grounds that those on the bottom of the hierarchy - the serfs, the villeins, or the prison-camp slaves - are accorded no respect at all. But we should remedy this by having more than one hierarchy, and, in so far as any one ranking system is dominant and generally accepted as constituting the social order, demanding that those who are deferred to should make manifest their respect and consideration for those who render them services (Lucas 1977, 267).

A man may not be a great success economically but still can be a big noise in the Boy Scout Association or the pigeon fanciers' club. So long as we have plenty of different inequalities, nobody need be absolutely inferior. It is only if, in the name of equality, we set about eliminating them all, that we shall succeed in eliminating many of them and thereby make those that remain far more burdensome (Lucas 1977, 268).

Although his tone somewhat betrays the message that no one need feel inferior, it is noteable that Lucas has hit upon the same basic idea as Scanlon, Rawls and Walzer in how to deal with the claimed problem that some forms of hierarchy and consequent inequality in self-worth, are an 
entrenched feature of human nature. What is remarkable is that while for Scanlon the suggestion is put forward as a way of achieving social equality, for Lucas it is, apparently, a model for an inegalitarian society. But there is apparent agreement that diversification, as Scanlon calls it, is the best route for preserving self-worth of all. Note, though, that this does not appear to be Tawney's view, for he seems to think that against the right background people will not need various forms of rare accomplishment in order to achieve a secure sense of self-worth. Freud, on the other hand, would probably argue that the Scanlon/Lucas proposal, alongside Tawney's, is illusory, as a dominant hierarchy will emerge, despite our efforts at containment or diversification. That is to say, even if one can be a 'big noise' in the boy scouts association, everyone will know that this doesn't really amount to anything when compared, say, to be a big noise in industry.

The question now becomes at least partly empirical. What level of social equality is it possible for human beings to achieve together, in mass society. Who is right? Freud, Tawney or Lucas? Perhaps they are all both right and wrong, in that their mistake is to think that there is a single truth of human nature, rather than different attitudes held by different people (or the same people at different times). It is quite possible that members of the same society will understand the sources of self-worth in different ways. Some may believe, like Freud, that there is a single dominant hierarchy, and that one's sense of self-worth should be related to the place one finds oneself in on that hierarchy. Others, like Rawls, Walzer, Lucas and possibly Scanlon, may believe that there are many spheres for achievement, and as long as what one does in at least one sphere is valued by others, self-worth [Page $\mathbf{4 2 3} \rightarrow$ ] will be secured. And finally there may be those who, like Tawney, feel that a sense of self-worth does not depend on particular achievements, but by social solidarity.

\section{Scanlon, Lucas and Tawney Revisited}

Although it appears that Scanlon's equality converges, in one respect at least, with the apparently anti-egalitarian position of Lucas, still it does not follow that their positions are the same in every respect. It is worth asking, therefore, how much material inequality each is prepared to endorse. As I understand it, Lucas would not want to put any limit of economic wealth, as this is merely one sphere among others, and those who do badly economically, as long as they are not in severe poverty, can obtain all they need for a decent life in other spheres. Scanlon's view is rather different. For him a good deal depends on how it is people came to be become wealthy and what that wealth enables them to do. So, for example, if the wealthy members of our society are celebrities and sports stars, who spend their wealth on consumer goods, then there need be no objection. But if they are CEOs of large companies, who have voted themselves and their friends high salaries and bonuses, then there may be some sort of procedural unfairness. And, finally, if wealthy people use their resources to control and dominate others, then there is an egalitarian objection. In all of this Scanlon is, once more, close to Tawney, although the class-based analysis 
one sees in Tawney is only barely present in Scanlon's presentation.

The point about social class is worth considering further. Consider two forms of inegalitarian society. The first is the picture that so worries Tawney. There are relations of domination and oppression, and one's place in this hierarchy is largely already determined by birth. Those born into privilege will remain powerful; very few of those born into families suffering from domination will escape. The second is a society which, in any generation, looks the same as the first, but in fact there is no relation between one's position at birth and where one ends up as an adult. There is no systematic reproduction of patterns of domination. From the point of view of social equality both are disastrous. Yet the second displays forms of egalitarianism that the former lacks; a rather brutal form of equality of opportunity, but also an end to the 'religion of inequality' or the belief in natural social partition. Perhaps, then, this is what a class-based analysis adds; it reveals a depth to inequality that will not be apparent otherwise. For as long as there [Page $424 \rightarrow$ ] is entrenched domination then entrenched social division remains and equality of opportunity is a myth. This is a further reason for observing that although Scanlon's objections to inequality are diverse, there can be, nevertheless, powerful interaction effects between them.

One can also ask how Lucas might regard Scanlon's objections concerning power and domination, and equality of opportunity. Lucas, it appears, has little to say on these matters. Unlike Tawney, it appears that he would have little objection if the great majority of high civil servants and judges were all drawn from the same public schools, and were the sons (not even the sons and daughters) of other civil servants and judges. Reproduction of hierarchy would not present a problem for him, as long as there were numerous hierarchies. Scanlon, one assumes, would side with Tawney, although possibly the absence of an explicit class-based analysis makes this a more difficult point for him to express, if it can be done at all. On a purely individualistic basis there can be no such thing as reproduction of patterns of inequality over the generations.

In conclusion, it appears, therefore, that while Scanlon emphasizes that the objections to inequality are diverse, Tawney may convince us that they are much more powerful in combination. Although it may well be that they do not determine a single model of an egalitarian society, they do, together, place substantial constraints on what may be permitted consistently with egalitarianism. Scanlon's position, I would suggest, is a modification of Tawney's. Scanlon and Tawney share a humanitarian concern for avoidance of poverty, together with an egalitarian concern opposing reproduction of inequalities of power, self-worth, and privilege. They differ, however, in a number of respects. First, Tawney's analysis focuses on social class, whereas class is largely absent in Scanlon's presentation. Here, I think, Tawney may have the advantage, for the idea of reproduction of inequality through the generations - and hence opposition to such practices makes little sense unless one social class has access to such things and another is excluded. 
Second, Scanlon is more exercised than Tawney by the apparent inevitably of the development of hierarchies of status and self-worth. Scanlon's concern, certainly, should be taken seriously. Thirdly, Scanlon's account of material equality is rather more individualistic than Tawney's. Scanlon's discussion of material equality at least appears to pre-suppose that what is at issue is equal division of material goods. Tawney, on the other hand, seems to feel that in respect of material goods egalitarians should aim for common provision of the most important goods, both because in fields such as education and health much more can be done by collective spending, and because it will focus attention away from pecuniary and [Page $425 \rightarrow$ ] commercial matters. On this last matter, no doubt, further work is needed on the ideal balance between individual and collective provision. ${ }^{1}$

Anderson Elizabeth (1999) 'What is the point of equality?' Ethics, 109: 287-337.

Arnold, Matthew ([1879] 2008) Mixed Essays Toronto: Bastian Books.

Barry, Brian (2005) Why Social Justice Matters (Oxford: Polity).

Dworkin Ronald (1981a) "What is Equality? Part 1: Equality of Welfare", Philosophy \& Public Affairs, 10: 228-240.

Dworkin, Ronald (1981b) 'What is Equality? Part 2: Equality of Resources', Philosophy \& Public Affairs, 10: 283-345.

Fraser, Nancy and Honneth Axel (1998), Recognition or Redistribution? (London: Verso).

Freud, Sigmund (1930) Civilization and Its Discontents (London: Hogarth).

Lewis, Arthur (1949) The Principles of Economic Planning (London: George Allen and Unwin).

Lucas, J.R. (1965) 'Against Equality', Philosophy, 40: 296-307.

Lucas, J.R. (1977) ‘Against Equality Again', Philosophy, 52: 255-280.

\footnotetext{
${ }^{1}$ I am particularly grateful to Tim Scanlon and Jerry Cohen for their comments on earlier versions of this paper, as well as to the members of the audience at the University of Manchester where this paper was presented, and to Thom Brooks and an anonymous reader for this journal.
} 
Marx, Karl (1875), Critique of the Gotha Programme.

Menger, Anton (1899), The Right to the Whole Produce of Labour (London: McMillan).

Scanlon, T.M. (1975), 'Preference and Urgency', Journal of Philosophy 72: 655-699.

Scanlon, T.M. (1976), 'Nozick on Rights, Liberty and Property', Philosophy and Public Affairs 6: 325.

Scanlon, T.M. (1996), The Diversity of Objections to Inequality, The Lindley Lecture, University of Kansas.

Scanlon, T.M. (2006) 'Justice Responsibility and the Demands of Equality' in The Egalitarian Conscience: Essays in Honour of G.A. Cohen, ed. Christine Sypnowich,

pp. 70-87 (Oxford: Oxford University Press).

Scanlon, T.M. (unpublished a) 'Plural Equality'

Scanlon, T.M. (unpublished b) 'When Does Equality Matter?'

Scheffler, Samuel (2003) “What Is Egalitarianism?" Philosophy and Public Affairs 31: 5-39.

Sen's , Amrtya (1980) 'Equality of What?' in (ed.) S.M. McMurrin, Tanner Lectures on Human Values, Vol. i. Salt Lake City: University of Utah Press; and Cambridge, UK: Cambridge University Press.

I

Walzer, Michael (1983) Spheres of Justice (New York, Basic Books).

Weithman, Paul (2004) 'Review of Scanlon, The Difficulty of Tolerance' Ethics 114 836-843.

Williams, Bernard (1962), 'The Idea of Equality', in Philosophy, Politics and Society, 2nd ser., ed. Peter Laslett and W. G. Runciman (Oxford: Blackwell).

World Health Organisation, Commission on the Social Determinants of Health, Closing the Gap in a Generation 2008. 
Wolff, Jonathan (1998), "Fairness, Respect and the Egalitarian Ethos", Philosophy and Public Affairs 1998, 27: 97-122.

Young, Iris Marion (1990), Justice and the Politics of Difference (Princeton: Princeton University Press). 